\title{
Brief history of Eucalyptus breeding in Brazil under perspective of biometric advances
}

\author{
Breve histórico do melhoramento genético do eucalipto no Brasil \\ sob a ótica dos avanços biométricos
}

\author{
Carla Aparecida de Oliveira Castro ${ }^{I}$ Rafael Tassinari ResendeII \\ Leonardo Lopes BheringII Cosme Damião Cruz ${ }^{\text {II }}$
}

\begin{abstract}
Forest breeding is a science that has been developing in Brazil since 1941 being the Eucalyptus a highlighted genus in this scenario. In a global scene, Brazil is displayed prominently in productivity of Eucalyptus planting, due to favorable environmental conditions to cultivation development, and the incentive in research for improvement of traits of interest $t$ observed in it species and hybrids. This research included a historical review of Eucalyptus breeding over the years under genetic biometric perspective in Brazil, from reports describing the pioneer planting up to the current genome wide selection (GWS) that came as a complement of forest breeding success. This review showed some of the tracks performed by researchers aiming to improve the productive and quality of phenotypic traits from Eucalyptus genus.
\end{abstract}

- REVIEW
Key words: genetics, crossing, history, current scenario, biometry, genomic.

\section{RESUMO}

O melhoramento florestal é uma ciência que tem tido desenvolvimento no Brasil desde o ano de 1941 e um gênero que obteve grande repercussão neste cenário foi o Eucalyptus. $O$ Brasil apresenta-se em destaque no panorama mundial quanto à produtividade dos plantios de eucalipto, em virtude das condições ambientais favoráveis ao desenvolvimento da cultura e ao incentivo em pesquisas destinadas às melhorias dos caracteres de interesse, presentes em suas espécies e híbridos. Este trabalho inclui uma revisão histórica do melhoramento do eucalipto ao longo dos anos no Brasil, sob a ótica da genética biométrica, desde o relato que descreve o plantio pioneiro de suas espécies no país, até a atual aplicação de seleção genômica ampla (SGA), que surgiu como um complemento de sucesso no melhoramento florestal. A pesquisa ilustra ainda alguns dos caminhos percorridos por pesquisadores a fim de aumentar a produtividade e a qualidade dos caracteres fenotípicos do gênero Eucalyptus.
Palavras-chave: genética, cruzamento, história, cenário corrente, biometria, genômica.

\section{INTRODUCTION}

It is hard to precisely define the Eucalyptus introduction time in Brazil, due the record differences (made by several authors) and the lack of documents proving the citations concerning possible entry dates of seeds and seedlings in the country. It is believed that the first Eucalyptus seedlings were planted in Brazil in 1824 at Rio de Janeiro Botanical Garden (BERTOLA, 2013; MARCHIORI, 2014).

Studies with Eucalyptus in Brazil began at 1904 by Edmundo Navarro de Andrade (in the Companhia Paulista de Estradas de Ferro), who introduced several species and origins of the genus in Jundiaí Garden, São Paulo. In this pioneer study, he aimed to establish the Eucalyptus usage in order to attend the existed wood demand that would be intended to railways construction (SAMPAIO, 1961).

The interest in these studies emerged due to Eucalyptus species presents an easy adaptation to different environmental conditions existed in Brazil, similar latitude with Australia and due to properties that give it several possibilities on wood usage. Currently, this genus is considered one of the most important planted in the country and in other tropical and subtropical regions of the world.

\footnotetext{
IDepartamento de Engenharia Florestal, Centro de Ciências Agrárias (CCA), Universidade Federal de Viçosa (UFV), 36570-900, Viçosa, MG, Brasil. E-mail: carla.castro0120@gmail.com. Corresponding author.
}

IDepartamento de Biologia Geral, Centro de Ciências Biológicas e da Saúde (CCB), Universidade Federal de Viçosa (UFV), Viçosa, MG, Brasil. 
In the last years, planted areas with those culture genotypes are in expansion process but with less intensity, due the increase of wood production costs. Moreover, this negative factor related to Eucalyptus cultivation stimulates research in genetic breeding and forest management to step-up this scenario.

The use of breeding tools supported by biometric statistics and the incentive of breeding programs (looking for production of high force hybrids) places Brazil among the most efficient countries for production of raw material from Eucalyptus. This scenario demonstrates the economical and social importance of Eucalyptus cultivation and the historical landmark that represents the introduction of its species in Brazil (ASSIS, 2014).

\section{DEVELOPMENT}

\section{Eucalyptus breeding overview}

Eucalyptus breeding aims to increase productivity, enabling to obtain higher traits performance and reduce environmental impacts (GOLLE et al., 2009). In this sense, different strategies are established combining crossing designs, selection methods and populations structure; aiming to increase alleles frequency of interest (RESENDE, 2000), which result in genotypic improvements of offspring.

By the same perspective, biotechnology has emerged as a complement in order to provide better understanding of genotype species and to enable indirect obtaining of predicted genotypic data with high reliability at each cycle, reducing its time (GOLLE et al., 2009).

The evidence of efficiency in Eucalyptus breeding programs can be obtained from individuals genetic values predictions using BLUP (best linear unbiased prediction), which allows selective accuracy maximization, use of information from different locations and is superior to the least square method (RESENDE, 2007). Effectiveness can also be measured by genetic gains estimation for a time period, so that it is possible to perform selection of traits of interest in the species. Therefore, it is crucial to understand the variability between and within populations as well as the related genetic control (VENCOVSKY, 1986).

At figure $1 \mathrm{~A}$ is possible to observe the mean annual increment (MAI) of Eucalyptus productivity in the last 45 years (IBÁ, 2015). This increase may be explained by the management techniques and forestry improvements, and mainly by the genetic breeding of planted trees. The number of publications produced in Brazil and in the world, during the same period is shown in figure $1 \mathrm{~B}$. These numbers were obtained from research in current journals, using keywords related to breeding, biometrics and Eucalyptus. It is noted that the volumetric productivity tends to stabilize in the coming years, while the total number of publications keep increasing, showing that other traits such as the technological quality of the wood, have the potential to be improved. We can see also that publications in Brazilian Portuguese language are stagnating suggesting that native researchers have opted for foreign journals.

\section{Eucalyptus breeding history in Brazil}

In 1941, Edmundo Navarro invited Carlos Arnaldo Krug, from the Instituto Agronômico de Campinas (IAC), to start a Eucalyptus breeding program in Brazil. To this aim, they held provenances testing, evaluating which would be the genus of species able to be planted in Brazil.

The Forestry Institute of São Paulo State assigned the activities of the Companhia Paulista de Estradas de Ferro in 1964. But only from 1967, with implementation of the Law of Tax Incentives for Reforestation, an intensive program of genetic breeding through the selection of superior trees started (beginning of national scientific publications, shown in Figure 1).

In order to produce improved seeds and know the provenances, some private forestry companies founded the Instituto de Pesquisas e Estudos Florestais (IPEF), located at Escola Superior de Agricultura "Luiz de Queiroz" (ESALQ) in 1968 (FERREIRA, 1993). Planting were performed with seeds; however, they quickly observed that trees from this type of spread had low productivity and problems with pathogens. In order to minimize this issue, different species were crossed to form hybrids, aiming to use the best potential of each (ASSIS et al, 1987; MARTINS \& IKEMORI, 1987). This promoted the increased force and reduced the susceptibility to diseases due heterosis, having the canker resistance (Chrysoporthecubensis) as example. Canker resistance was a relevant trait for that time, as the first major outbreak of that disease appeared at the end of $60 \mathrm{~s}$; subsequently described by the HODGES \& REIS (1974) work.

In the mid-70s, research on biometrics and quantitative genetics gained strength with the partnership between Paulo Yoshio Kageyama and Roland Vencovsky, both researchers from ESALQ, who performed genetic parameters calculations and studies about the optimal implementation of genetic experiments with Eucalyptus. 


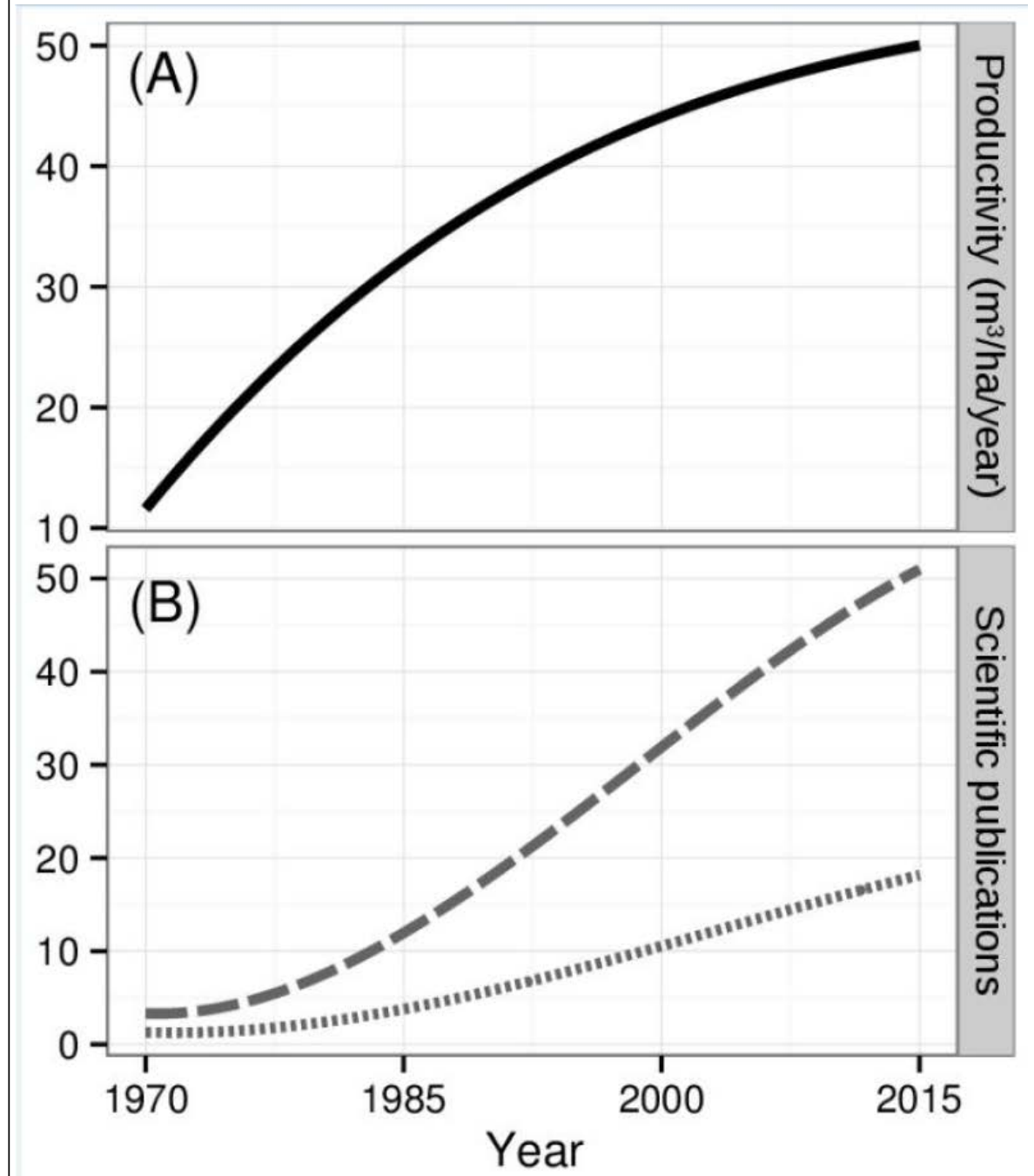

\section{Language $=-$ All}

Figure 1 - (A) Mean annual increment (MAI) of Eucalyptus productivity (Source: adapted from IBÁ, 2015). (B) Scientific Publications with keywords related with genetic breeding, biometric and Eucalyptus. Dashed line corresponds to publications in both English and Portuguese; dotted line corresponds to publications only in Portuguese-Brazil language. Both A and B periods range from 1970 to 2015 .

With the premise that genetic material of Eucalyptus populations was being improved by crosses that combined genotypes of interest within and between families, a growing interest in conducting progeny tests was observed aiming to analyze the genetic gains obtained across generations. It was observed that the expected gains in a population were not always consistent with those observed in the field; being these differences caused by the interference of environmental conditions during planting process. Because of that, there was a growing interest in studies aiming to compare the interaction between genotypes of different species and the environment in which they were inserted. (KAGEYAMA, 1983; PATIÑO \& VALERA, 1986; MORI et al, 1886; VALERA \& KAGEYAMA, 1988; SANTOS et al., 1990).

The 1980-1995 period was characterized by less emphasis related to breeding strategies using crossing methods, giving greater emphasis on 
clonal propagation, since it was proved that cloning originated greater uniformity and enabled great gains in selection cycle. However, companies and research groups have reported that high selective intensity causes variability decrease in the base population making it impossible to maintain the gains during the breeding program.

As a result, breeding and selection programs were encouraged in order to enhance the population to obtain better interspecific hybrids. Several selection methods were studied for defining viability of Eucalyptus breeding programs (RESENDE et al., 1990; RODRIGUES et al., 2008; ROSADO et al., 2009; MASSARO et al., 2010; PINTO et al., 2014). Among these methods, those using genetic additive values, based on the known population structures or molecular and genomic descriptions, have been highlighted due to advantages in the individuals characterization in the population compared to the selection only based on phenotypic values (RESENDE \& HIGA, 1994).

From a detailed historical analysis, it is possible to see the incentive to technical findings that were fundamental to obtain an increase in forest productivity (ASSIS, 2014). Thus, selection of more productive genotypes became a goal for breeding, reducing the planting area and the use of supplies.

Biometric advances based on phenotypic traits study To evaluate the genetic material, some information is obtained directly from individual phenotype in the experiment, such as growth, tree shape, resistance to biotic and abiotic factors and wood properties. Being that, used as a criteria for different phenotypes selection to evaluate genetic gains (NUNES et al., 2002; ROSADO, 2009).

Genetic gain depends on heritability $\left(h^{2}\right)$, which assists in strategies of breeding program planning, requiring attention when dealing with low $\mathrm{h}^{2}$ traits. Some ${ }^{2}$ values of Eucalyptus traits are presented in table 1 (RAYMOND (1995) and CORNELLIUS (1994) cited by PIRES et al. (2011). Besides this biometric parameter, repeatability and genetic correlation are also relevant in Eucalyptus breeding; whereas, several variables and measurements can be taken from the same tree. Moreover, being a long cycle cultivation, wait 6 or 7 years of production cycle to perform the variables measurement becomes economically unfeasible, while using early selection is feasible to get it after 3 or 2 years of planting (KAGEYAMA, 1983; MASSARO et al., 2010; PINTO et al., 2014.). Usually, GENES (CRUZ, 2013) and Selegen REML/BLUP (RESENDE, 2002) programs are used to calculate these parameters and genotypic values predictions.

REML/BLUP procedure and least squares method (LSM) allowed the genetic evaluation regarding the selection gains obtained from breeding, prioritizing individuals with higher genetic additive values. It is believed that the REML/BLUP efficiently selects individuals, families and progeny even in the presence of unbalanced data (very common event in Eucalyptus stands). In the research performed by ROCHA et al. (2006), it was observed genetic variability existence and possibility of selection by gains in diameter at breast height (DBH), height and volume traits, with accuracies above $70 \%$.

In many Eucalyptus species, biometric parameters were estimated using progeny tests, which showed that $\boldsymbol{E}$. camaldulensis and $\boldsymbol{E}$. resinifera have high potential to be explored by selection and thus can be used in breeding programs (MORAES et al., 2007, SATO et al., 2007). There has also been interest in identifying Eucalyptus clones that are wide adapted, that is, the most stable to environmental changes (TOLER, 1990). This specification may be used to evaluate the effect of different conditions in clones (genotype $\mathrm{x}$ environment interaction, or $\mathrm{G} \times \mathrm{E}$ ) and how this affects wood volume (NUNES et al., 2002).

Pulp and paper industry are very important for biometric studies. It should be remembered that several traits like pulp yield, lignin, extractives and fibers length (HILLIS, 1972) are critical to be considered in breeding. Companies commonly use $\boldsymbol{E}$. grandis and $\boldsymbol{E}$. urophylla for cellulose production, but genetic gains in several traits of interest interspecific crosses are made in order to form promising hybrids for better pulp quality production (BISON, 2007; RESENDE\& DE ASSIS, 2008).

Another important product from Eucalyptus wood is charcoal, and aspects of phenotype, genotype, environmental and to indirect genetic gains should be analyzed to obtain superior features. The most used species for charcoal production are $\boldsymbol{E}$. urophylla, E. camaldulensis, $\boldsymbol{E}$. cloeziana and $\boldsymbol{E}$. pellita. In biometric studies, selection is based on gravimetric yield of charcoal, basic and relative apparent density, lignin content and fixed carbon yield (CAIXETA et al., 2003; BOTREL et al., 2007; RODRIGUES et al., 2008).

As could be seen, among the species of Eucalyptus spp. genus there are those with particular properties for several uses, including the possibility of using for essential oil production (E. citriodora) and lumber (E. grandis, E. saligna and E. pirulalis). This 
Table 1 - Narrow-sense individual heritability estimates $\left(\mathrm{h}^{2}{ }_{\mathrm{a}}\right)$ of technological and Eucalyptus wood growth traits.

\begin{tabular}{lcl}
\hline Trait & $\mathrm{h}^{2}{ }_{\mathrm{a}}$ (Mean) & $\mathrm{h}^{2}$ (Amplitude) \\
\hline Height & 0.25 & - \\
Diameter & 0.23 & - \\
Volume & 0.21 & - \\
Basic density & 0.57 & $0.05 \mathrm{a} 0.84$ \\
Kraft Pulp yield & 0.43 & $0.30 \mathrm{a} 0.56$ \\
Fiber length & 0.39 & $0.12 \mathrm{a} 0.59$ \\
Pilodyn penetration & 0.49 & $0.21 \mathrm{a} 0.78$ \\
Soda Demand & 0.50 & $0.20 \mathrm{a} 0.74$ \\
Moisture Content & 0.48 & $0.28 \mathrm{a} 0.82$ \\
Fiber diameter & 0.89 & - \\
Lumen diameter & 0.59 & - \\
Vessel Diameter & 0.67 & - \\
\hline
\end{tabular}

Source: RAYMOND (1995) and CORNELLIUS (1994). Cited by PIRES et al., 2011 .

information is important for inter-specific crosses guidance aiming to get the best of each species.

Disease resistance is another issue that is studied, since the incidence of pathogens affect forest productivity. Rust, canker and wilt of Eucalyptus are examples that can be cited among the common incidence of diseases in its plantations that are widely disseminated throughout Brazil. Breeders attempted to select resistant individuals to these and other pathogens, and implement new breeding techniques to ensure plantations health, as it causes serious damage in nurseries, plantations, and wood quality (ZAUZA et al., 2004; ZAMPROGNO et al., 2008; TEIXEIRA et al., 2009; GUIMARÃES et al., 2010).

Such evaluated traits in Eucalyptus species have particular genetic properties as different $h^{2}$ (Table 1), additive genetic variance, and dominance (LYNCH \& WALSH, 1998). In this context, RESENDE \& BARBOSA (2005) summarizes in their book (Melhoramento Genético de Plantas de Propagação Assexuada) strategies based on recurrent selection that are perfectly suitable to these traits improvement.

Biometric advances based on genetic information study

Evaluating the current economic and environmental importance of Eucalyptus species cultivation, it is noted the need to link breeding practices with existing and emerging genomic tools (GRATTAPAGLIA, 2004). Thus, both technology of molecular markers and techniques of classical breeding have significantly contributed to an improved knowledge of Eucalyptus cultivation, and for improved genotypes generation.

One of the proposals of molecular markers usage is the ability to identify the genetic relationship between individuals in a population, not requiring detailed information of kinship/pedigree among the trees (MUÑOZ et al., 2014). STEANE et al. (2011) proposed an approach to identify Eucalyptus species and its hybrids with high reliability; a valuable information on Eucalyptus breeding, as the knowledge of rates from different species and hybrids is often missed along the program.

Genetic variability knowledge is important at many stages of reproductive cycle, being enhanced by the use of molecular markers. In this sense, techniques can be performed as the use of Eucalyptus spp. microsatellite (SSR), in terms of a co-dominant marker and highly polymorphic (SANTOS et al., 2007).

The GENOLYPTUS project (National Network of Eucalyptus Genome Research) has emerged as a strategic maneuver of Brazilian forestry companies, aiming to encourage research and development in genetic, breeding, molecular markers and cloning of this genus in the country (GRATTAPAGLIA, 2001).

MYBURG et al. (2014) revolutionized the genotyping process by performing the complete mapping of $\boldsymbol{E}$. grandis genome, being this information highly relevant to other species of the Eucalyptus genus and its hybrids. In this context, an Illumina $60 \mathrm{~K}$ chip for large-scale genotyping of 12 Eucalyptus species were developed (SILVA-JUNIOR et al., 2015), being the landmark that consolidates the use of single nucleotides polymorphisms (SNP) in genomic studies of the genus.

Individual DNA is the source that determines their traits expression at a first moment; however, it is known that the environment in which it is inserted influences the phenotype expression. In order to perform Eucalyptus breeding programs, phenotypes knowledge is essential in addition to genotype-markers, so it is possible to select trees that tend to be genetically superior within the population. Furthermore, the genomic approach allows detailed understanding of genetics aspects as heterosis and inbreeding (GRATTAPAGLIA et al., 2012; HEDRICK et al., 2015).

Mapping and detection of quantitative trait loci (QTL) is a biometric procedure that allows inferring about the genetic architecture of the trait, indicating genes and the effects related to it expression. 
Authors identified QTLs for Eucalyptus traits, such as growth, disease resistance and wood properties (GRATTAPAGLIA et al., 1996; THAMARUS et al., 2004; THUMMA et al., 2010; ZARPELON et al., 2015). However, for selection purposes, QTLs have not shown good results for traits with low $\mathrm{h}^{2}$ (RESENDE et al., 2008).

Seminal studies in Brazil performed by RESENDE et al. (2008), indicated that the use of Genome Wide Selection method called (GWS) gave positive results for traits with both high and low $\mathrm{h}^{2}$ in Eucalyptus spp. Unlike other molecular breeding methods, GWS has achieved high predictive accuracies due the ability to capture three sources of genetic variation: (i) Linkage disequilibrium (ii) Co-segregation and (iii) genetic relationship (kinship via identity by state). For this, all markers of the genome should be used simultaneously (RESENDE, 2010).

Genomic selection effectiveness has been validated in different populations of Eucalyptus, and predictive models have been developed for many traits of tree by predictions via BLUP (RESENDE et al., 2012). Moreover, RESENDE (2010) and RESENDE et al. (2012) highlighted reductions of trial period from 6 years to only one for growth variables and wood properties. This selection method brought a new perspective for understanding quantitative traits variation in Eucalyptus and appears as an advanced tool for modern forest breeding.

\section{CONCLUSION}

Methods used in Eucalyptus forest breeding have been improved since 1941. Initially, it was invested in breeding based on phenotypic means and improved seed obtaining, and further in hybridization and cloning methods. Adaptability and stability studies in many environments were also performed to identify genotypes with specific behavior in different locations.

Being a long cycle cultivation, growing efforts to reduce the selection period was observed, which resulted in early selection with a reduction of less than a half of the evaluation time. Biotechnology has also shown efficiency related to early selection use, reducing even more the trial period through genomic selection methods, in addition to enabling the determination of genetic relationship degree between individuals. Despite the obtained progress, it is possible to expect a stagnation in volumetric growth improvement, which encourages studies related to genetic improvements in wood technological traits.

\section{ACKNOWLEDGMENTS}

Authors thank Guilherme Simiqueli and Haroldo Silva Rodrigues for his help in proof reading; Conselho Nacional de Desenvolvimento Científico e Tecnológico (CNPq), Coordenação de Aperfeiçoamento de Pessoal de Nível Superior (CAPES) and Fundação de Amparo à Pesquisa do Estado de Minas Gerais (FAPEMIG) for providing research grants and Professor Marcos Deon Vilela Resende by scientific advice.

\section{REFERENCES}

ASSIS, F.T. et al. Produção de híbridos interespecíficos em Eucalyptus spp. In: REUNIÃO SOBRE TÉCNICAS PARA PRODUÇÃO DE HÍBRIDOS, 1987, Piracicaba, São Paulo. Anais... Piracicaba: IPEF, 1987. p.2-5.

ASSIS, T.F. Melhoramento genético de Eucalyptus: desafios e perspectivas. Nova Lima: Embrapa Florestas, 2014. 22p. Available from: <http:/www.expoforest.com.br/silvicultura/wp-content/ uploads/2013/09/encontro-silvicultura-2014-bloco-2-pdfartigo-pag-127.pdf $>$. Accessed: Apr. 14, 2016.

BERTOLA, A. Eucalipto - 100 anos de Brasil- "Falem mal, mas continuem falando de mim!"’. Setor de Inventário Florestal V\&M Florestal Ltda, Curvelo - MG, 91p., 2013. Available from: $<$ http://www.celso-foelkel.com.br/artigos/outros/ Eucalipto_100\%20anos\%20de\%20Brasil_Alexandre_ Bertola.pdf $>$. Accessed: Apr. 14, 2016.

BISON, O. et al. Combining ability of elite clones of Eucalyptus grandis and Eucalyptus urophylla with Eucalyptus globulus. Genetics and Molecular Biology, v.30, n.2, p.417-422, 2007. Available from: <http://www.scielo.br/pdf/gmb/v30n2/ a19v30n2.pdf>. Accessed: Apr. 14, 2016. doi: 10.1590/S141547572007000300019.

BOTREL, M.C.G. et al. Genetic improvement of Eucalyptus charcoal properties. Revista Árvore, v.31, n.3, p.391-398, 2007. Available from: <http://www.scielo.br/pdf/rarv/v31n3/04.pdf > Accessed:Apr. 14, 2016. doi: 10.1590/S0100-67622007000300004.

CAIXETA, R.P. et al. Properties and classification of wood for selecting Eucalyptus genotypes. Revista Árvore, Viçosa, v.27, n.1, p.43-51, 2003. Available from: $<$ http://www.scielo.br/pdf/rarv/ v27n1/15920.pdf>. Accessed: Apr. 14, 2016. doi: 10.1590/S010067622003000100006 .

CORNELLIUS, J. Heritabilities and additive genetic coefficients of variation in forest trees. Canadian Journal of Forestry Research, v.24, p.372-379, 1994. Available from: <http:// www.nrcresearchpress.com/doi/abs/10.1139/x 94-050\#. VxaW73ErKUl>. Accessed: Apr. 14, 2016. doi: 10.1139/x94-050.

CRUZ, C.D. Genes: a software package for analysis in experimental statistics and quantitative genetics. Acta Scientiarum. Agronomy, v.35, n.3, p.271-276, 2013.

FERREIRA, M.A. Contribuição do setor de sementes do LCF/ IPEF para a silvicultura intensiva brasileira. IPEF. n.46, p.8-31, 
1993. Available from: <http://www.ipef.br/publicacoes/scientia/ nr46/cap01.pdf>. Accessed: Apr. 14, 2016.

GOLLE, D.P. et al. Forestry improvement: emphasis on biotechnology application. Ciência Rural, v.39, n.5, p.1606-1613, 2009. Available from: $<$ http://revistas.bvs-vet.org.br/crural/article/ viewFile/19755/20593>. Accessed: Apr. 14, 2016. doi: 10.1590/ S0103-84782009000500050

GRATTAPAGLIA, D. et al. Genetic mapping of quantitative trait loci controlling growth and wood quality traits in Eucalyptus grandis using a maternal half-sib family and RAPD markers. Genetics, v.144, n.3, p.1205-1214, 1996. Available from $<$ http://www.genetics.org/content/genetics/144/3/1205.full.pdf $>$. Accessed: Apr. 14, 2016

GRATtAPAgliA, D. Genolyptus-Rede Brasileira de Pesquisa do Genoma de Eucalyptus. Colombo: Embrapa Florestas, 2001. p. 61. Available from: <https://www.infoteca.cnptia.embrapa.br/ infoteca/bitstream $/$ doc $/ 306094 / 1 /$ doc62.pdf\#page=57>. Accessed: Apr. 14, 2016

GRATTAPAGLIA, D. Integrating genomics into Eucalyptus breeding. Genetics and Molecular Research, v.3, n.3, p.369379, 2004. Available from: <http://www.funpecrp.com.br/ gmr/year2004/vol3-3/gmr0109_full_text.htm>. Accessed: Apr. 14, 2016.

GRATTAPAGLIA, D. et al. Progress in Myrtaceae genetics and genomics: Eucalyptus as the pivotal genus. Tree Genetics \& Genomes, v.8.3, p.463-508, 2012. Available from: <http:/ link.springer.com/article/10.1007\%2Fs 11295-012-0491x\#enumeration>. Accessed: Apr. 14, 2016. doi: 10.1007/s11295012-0491-x.

GUIMARÃES, L.M.S. et al. Genetic control of Eucalyptus urophylla and $\boldsymbol{E}$. grandis resistance to canker caused by Chrysoporthe cubensis. Genetics and molecular biology, v.33, n.3, p.525-531, 2010. Available from: <http://www.scielo.br/pdf/ gmb/v33n3/2009-223.pdf>. Accessed: Apr. 14, 2016. doi: 10.1590/ S1415-47572010005000069.

HEDRICK, P.W. et al. Examining the cause of high inbreeding depression: analysis of whole genome sequence data in 28 selfed progeny of Eucalyptus grandis. New Phytologist, v.209, n.2, p.600-611, 2016. Available from: <http://onlinelibrary.wiley. com/doi/10.1111/nph.13639/full>. Accessed: Apr. 14, 2016. doi: 10.1111/nph. 13639 .

HILLIS, W.E. Properties os Eucalypt woods of importance to the pulp and paper industry. Appita, v.26, n.2, p.113-122, 1972.

HODGES, C.S.; REIS, M.S. A influência do cancro basal causada por Diaporthe cubensis na brotação de Eucalyptus saligna SM Brasil Florestal, v.18, p.25-28, 1974.

IBÁ. Indicadores de desempenho do setor nacional de árvores plantadas referentes ao ano de 2014. Brasília, 2015. 80p. Available from: <http://iba.org/images/shared/iba 2015.pdf $>$. Accessed: Apr. 14, 2016.

KAGEYAMA, P.Y. Seleção precoce a diferentes idades em progênies jovens de Eucalyptus grandis W. Hill ex Maiden. Piracicaba: ESALQ, 1983. 147p. Tese (Livre Docência) - Escola Superior de Agricultura Luís de Queiroz, 1983.
LYNCH, M.; WALSH, B. Genetics and analysis of quantitative traits. Sunderland, MA: Sinauer, 1998. 980p.

MARCHIORI, J.N.C. Primórdios da silvicultura no Rio Grande do Sul. 1-Nota sobre a introdução do gênero Eucalyptus L'Her. Balduinia, n.44, p.21-31, 2014. Available from: <http:// cascavel.cpd.ufsm.br/revistas/ojs-2.2.2/index.php/balduinia/ article/view/14002/8736>. Accessed: Apr. 14, 2016. doi: $10.5902 / 23581980$

MARTINS, F.C.G.; IKEMORI, Y.K. Produção de híbridos de eucalipto na Aracruz. In: REUNIÃO SOBRE TÉCNICAS PARA PRODUÇÃO DE HÍBRIDOS, 1987, Piracicaba, SP. Anais... Piracicaba, IPEF, 1987. p.48-62.

MASSARO, R.A.M. et al. Early selection viability in Eucalyptus spp. clonal tests. Ciência Florestal, v.20, n.4, p.597-609, 2010. Available from: $<$ http://cascavel.ufsm.br/revistas/ojs-2.2.2/index. php/cienciaflorestal/article/view/2418>. Accessed: Apr. 14, 2016. doi: $10.5902 / 19805098$

MORAES, M.A. et al. Variação genética para caracteres silviculturais em progênies de polinização aberta de Eucalyptus camaldulensis em LuizAntônio-SP. Revista do Instituto Florestal São Paulo, v.19, n.2, p.113-118, 2007. Available from: <http:// agris.fao.org/agris-search/search.do?recordID=DJ2012069422>. Accessed: Apr. 14, 2016.

MORI, E.S. et al. Efeitos da interação genótipo x ambiente em progênies de Eucalyptus saligna Smith. IPEF, v.33, p.19-26, 1986. Available from: <http://ipef.br/publicacoes/scientia/nr33/ cap02.pdf $>$. Accessed: Apr. 14, 2016.

MUÑOZ, P.R. et al. Genomic relationship matrix for correcting pedigree errors in breeding populations: impact on genetic parameters and genomic selection accuracy. Crop Science, v.54, n.3,p.1115-1123, 2014. Available from: $<$ https://dl.sciencesocieties. org/publications/cs/abstracts/54/3/1115>. Accessed: Apr. 14, 2016. doi: $10.2135 /$ cropsci2012.12.0673.

MYBURG, A.A. et al. The genome of Eucalyptus grandis. Nature, v.510, n.7505, p.356-362, 2014. Available from: <http:/ www.nature.com/nature/journal/v510/n7505/pdf/nature 13308 . pdf $>$. Accessed: Apr. 14, 2016. doi: 10.1038/nature13308.

NUNES, B.H.S. et al. Implications of the genotype-environment interaction effects on Eucalyptus clone selection. Cerne, v.8, p.49-58, 2002. Available from: $<$ http://cerne.ufla.br/ojs/index.php/ CERNE/article/view/462/401>. Accessed: Apr. 14, 2016.

PATIÑO-VALERA, F. Variação genética em progênies de Eucalyptus saligna e sua interação com espaçamento. 1986. 192f. Dissertação (Mestrado em Engenharia Florestal) - Escola Superior de Agricultura Luiz de Queiroz - ESALQ, Piracicaba, 1986.

PINTO, D.S. et al. Early selection in tests for growth traits of Eucalyptus urophylla clones test. Scientia Forestalis, v.42, n.102, p.251-257, 2014. Available from: <http://www.ipef.br/publicacoes/ scientia/nr102/cap09.pdf>. Accessed: Apr. 14, 2016

PIRES, I.E. et al. Genética florestal. Viçosa (MG): Arka, 2011. $318 \mathrm{p}$.

RAYMOND, C.A. Genetic control of wood and fibre traits in Eucalyptus, In: POTTS, B.M. et al. (Eds.). Eucalypt plantations: 
improving fibre yield and quality. Hobart: CRC for Temperate Hardwood Forestry, 1995. p.49-52.

RESENDE, M.D.V.; BARBOSA, M.H.P. Melhoramento genético de plantas de propagação assexuada. Colombo: Embrapa Florestas, 1ed. 2005. 130p.

RESENDE, M.D.V. et al. Genome wide selection (GWS) and maximization of the genetic improvement efficiency. Pesquisa Florestal Brasileira, n.56, p.63, 2008. Available from: $<$ http://ainfo.cnptia.embrapa.br/digital/bitstream/CNPF-200909/44392/1/6_Deon.pdf>. Accessed: Apr. 14, 2016.

RESENDE, M.D.V. et al. Utilization of selection indexes in Eucalypt breeding. Boletim de Pesquisa Florestal, Colombo, n.21, p.1-13. 1990. Available from: <https://www.researchgate. net/profile/Antonio_Higa2/publication/255656690_utilizao de ndices de seleo no melhoramento de eucalipto/ links/53f3b3c10cf2155be352c3e6.pdf>. Accessed: Apr. 14, 2016.

RESENDE, M.D.V. et al. Genomic selection for growth and wood quality in Eucalyptus: capturing the missing heritability and accelerating breeding for complex traits in forest trees. New Phytologist, v.194, n.1, p.116-128, 2012. Available from: <http:// onlinelibrary.wiley.com/doi/10.1111/j.1469-8137.2011.04038.x/ pdf $>$. Accessed: Apr. 14, 2016. doi: 10.1111/j.14698137.2011.04038.x

RESENDE, M.D.V.; HIGA, A.R. Estimação de valores genéticos no melhoramento de Eucalyptus: seleção em um caráter com base em informações do indivíduo e de seus parentes. Boletim de Pesquisa Florestal, v.1, n.28-29, p.11-36, 1994. Available from: $<$ http://www.alice.cnptia.embrapa.br/bitstream/doc/282144/1/ mresende.pdf $>$. Accessed: Apr. 14, 2016.

RESENDE, M.D.V. Matemática e estatística na análise de experimentos e no melhoramento genético. Colombo: Embrapa Florestas, 542p. V.362. Available from: <http:// livraria.sct.embrapa.br/liv resumos/pdf/00083145.pdf $>$. Accessed: Apr. 14, 2016

RESENDE, M.D.V. Análise estatística de modelos mistos via REML/BLUP na experimentação em melhoramento de plantas perenes. Colombo: Embrapa Florestas, 2000. 101p. (Embrapa Florestas. Documentos, 47). Available from: $<$ http://ainfo.cnptia. embrapa.br/digital/bitstream/item/17057/1/doc47.pdf $>$. Accessed: Apr. 14, 2016.

RESENDE, M.D.V. Software SELEGEN-REML/BLUP Colombo: Embrapa Florestas, 2002. 65p. (Embrapa Florestas. Documentos).

RESENDE, M.D.V. et al. Computação da seleção genômica ampla (GWS). Colombo: Embrapa Florestas, 2010. 79p. Available from: <http://ainfo.cnptia.embrapa.br/digital/bitstream/ item/31426/1/Doc210.pdf>. Accessed: Apr. 14, 2016.

ROCHA, M.G.B. et al. Genetic evaluation of half-sib Eucalyptus urophylla progênies by the REML/BLUP and minimum squares procedure. Ciência Florestal, v.16, n.4, p.369-379, 2006. Available from: $<$ http://cascavel.ufsm.br/revistas/ojs-2.2.2/index. php/cienciaflorestal/article/view/1918/1160>. Accessed: Apr. 14, 2016. doi: 10.5902/19805098.

RODRIGUES, E.A.C. et al. Clone selection of Eucalyptus envisaging wood physical properties assessed on field conditions.
Cerne, v.14, n.2, p.147-152, 2008. Available from: <http://cerne. ufla.br/ojs/index.php/CERNE/article/view/269/221>. Accessed: Apr. 14, 2016

ROSADO, A.M. et al. Predicted genetic gains by various selection methods in Eucalyptus urophylla progenies. Pesquisa Agropecuária Brasileira, v.44, n.12, p.1653-1659, 2009. Available from: <http://seer.sct.embrapa.br/index.php/pab/article/ view/2267/5913> Accessed: Apr. 14, 2016. doi: 10.1590/S0100204X2009001200014

SAMPAIO, A.N. História. In: ANDRADE, E.N. O Eucalipto. 2.ed. São Paulo: Cia Paulista de Estradas de Ferro, 1961.p.58-64.

SANTOS, K.L. et al. Transference of microsatellite markers from Eucalyptus spp. to Acca sellowiana and the successful use of this technique in genetic characterization. Genetics and Molecular Biology, v.30, n.1, p.73-79, 2007. Available from: <http://www. scielo.br/pdf/gmb/v30n1/14.pdf $>$. Accessed: Apr. 14, 2016. doi: 10.1590/S1415-47572007000100014.

SANTOS, P.E.T. et al. Potencial para programas de melhoramento, estimativas de parâmetros genéticos e interação progênies x locais em populações de Eucalyptus urophylla S. T. Blake. IPEF, n.43/44, p.11-19, 1990. Available from: <http://www.ipef.br/ publicacoes/scientia/nr43-44/cap02.pdf > . Accessed: Apr. 14, 2016.

SATO, A.S. et al. Selection within progenies of Eucalyptus resinifera at 21 years old in Luiz Antônio - SP. Revista Instituto Florestal, v.19, n.1, p.93-100, 2007. Available from: $<$ http://www. iflorestal.sp.gov.br/RIF/RevistaIF/RIF19-2/RIF19-2 93-100.pdf>. Accessed: Apr. 14, 2016

TEIXEIRA, J.E.C. et al. Inheritance of resistance to Puccinia psidii G. Winter in a eucalyptus interspecific hybrid progeny evaluated under conditions of natural infection. Tropical Plant Pathology, v.34, p.203-210, 2009. Available from: <http://www. producao.usp.br/bitstream/handle/BDPI/5157/art_TEIXEIRA_ Analise da heranca da resistencia a Puccinia 2009. pdf? sequence $=1 \&$ is Allowed $=\mathrm{y}>$. Accessed: Apr. 14, 2016. doi: 10.1590/S1982-56762009000400001.

THAMARUS, $\mathrm{K}$. et al. Identification of quantitative trait loci for wood and fibre properties in two full-sib pedigrees of Eucalyptus globulus. Theoretical and Applied Genetics, v.109, n.4, p.856-864, 2004. Available from: <http://link.springer.com/ article/10.1007/s00122-004-1699-4\#/page-1>. Accessed: Apr. 14, 2016. doi: 10.1007/s00122-004-1699-4.

THUMMA, B.R. et al. Quantitative trait locus (QTL) analysis of wood quality traits in Eucalyptus nitens. Tree Genetics \& Genomes, v.6, n.2, p.305-317, 2010. Available from: <http:// link.springer.com/article/10.1007/s11295-009-0250-9\#/page-1>. Accessed: Apr. 14, 2016. doi: 10.1007/s11295-009-0250-9.

TOLER, J.E. Patterns of genotypic performance over environmental arrays. 1990.154f. Thesis (Ph.D)-Clemson University, Clemson.

VALERA, F.P.; KAGEYAMA, P.Y. Interação genótipo $\mathrm{x}$ espaçamento em progênies de Eucalyptus saligna Smith. IPEF, v.39, p.5-16, 1988. Available from: <http://www.ipef.br/ publicacoes/scientia/nr39/cap01.pdf>. Accessed: Apr. 14, 2016.

VENCOVSKY, R. Amostragem genética em populações naturais. Silvicultura, v.41, p.95-96, 1986. 
ZAMPROGNO, K.C. et al. Utilização de análise de segregantes agrupados na identificação de marcadores ligados a genes que controlam a resistência à ferrugem (Puccinia psidii Winter) em Eucalyptus sp. Summa Phytopathologica, v.34, p.253255, 2008. Available from: <http://repositorio.unesp.br/ bitstream/handle/11449/6129/S0100-54052008000300009. pdf? sequence $=1 \&$ isAllowed $=\mathrm{y}>$. Accessed: Apr. 14, 2016. doi: 10.1590/S0100-54052008000300009.

ZARPELON, T.G. et al. Genetic mapping and validation of QTLs associated with resistance to Calonectria leaf blight caused by Calonectriapteridis in Eucalyptus. Tree Genetics \& Genomes, v.11, n.1, p.1-9, 2015. Available from: <http:// link.springer.com/article/10.1007/s $11295-014-0803-$ 4\#page-1>. Accessed: Apr. 14, 2016. doi: 10.1007/s11295014-0803-4.

ZAUZA, E.A.V. et al. Resistance of Eucalyptus clones to Ceratocystis fimbriata. Plant Disease, v.88, p.758-760, 2004. Available from: <http://apsjournals.apsnet.org/doi/pdf/10.1094/ PDIS.2004.88.7.758>. Accessed: Apr. 14, 2016. doi: 10.1094/ PDIS.2004.88.7.758. 